5 ) Kataoka, H.: J. Chem. Engng. Japan, 8, 271(1975)

6 ) Kataoka, H., H. Doi, T. Hongo and M. Futagawa: ibid., 8, 472 (1975)

7 ) Kataoka, K., H. Doi and T. Komai: Int. J. Heat Mass Transfer, 20, 57 (1977)

8 ) Maron, D.M. and S. Cohen: Advances in Heat Transfer, Academic Press., 21, 141 (1991)
9 ) Mizushina, T., R. Ito, K. Kataoka, S. Yokoyama, Y. Nakajima and A. Fukuda: Kagaku Kōgaku, 32, 795 (1968)

10) Mizushina, T., R. Ito, K. Kataoka, Y. Nakajima and A. Fukuda: ibid., 35, 1116 (1971)

11) Tachibana, F., S. Fukui and H. Mitumura: JSME, 25, 788 (1959)

\title{
Heat Transfer in Vertical Concentric Cylinders with an Inner Rotating Cylinder
}

\author{
Sinzo Nishikawa
}

Mitsubishi Rayon Central Research Laboratory, Ohtake 739-06

Key Words : Heat Transfer, Concentric Rotating Cylinders, Taylor Number

Overall heat transfer coefficients in vertical concentric cylinders were measured for methyl methacrylate syrup and vinyl acetate syrup, and a dimensionless equation for the film heat transfer coefficient was derived.

In the case of methyl methacrylate syrup, the Nusselt number with respect to the overall heat transfer coefficient varied with breadth of annulus and gradually approached 2 as the Taylor number decreased within the laminar flow range of $T a<41$. Vinyl acetate syrup, a non-Newtonian fluid, had a Couette flow pattern in a wide range of modified Taylor number, i.e. $1.3<T a / F_{g}{ }^{0.5}<41$

\section{機能性マグネタイト微粒子によるモノクローナル 抗体の迅速な精製法の確立 ${ }^{\dagger}$}

\author{
新海政重・上平正道・本多裕之・小林 猛 \\ 名古屋大学工学部 生物機能工学科 ${ }^{\dagger \dagger}$
}

モノクローナル抗体は微量分析や医療・診断などへの 利用が期待され近年注目されている。特にモノクローナ ル抗体を医療に用いる場合，抗体の大量処理および高純 度化が必要とされる，通常，抗体の精製にはゲル沪過， イオン交換クロマトグラフィー, アフィニティークロマ トグラフィーなどのカラムクロストグラフィーが用いら れる.しかし，てれらのカラムクロマトグラフィーはそ の操作に長時間を要するため, 迅速かつ簡便な精製方法

† 1991年 7 月 25 日受理

†† $\mathbf{9} 464-01$ 名古屋市千種区不老町
が望まれている，最近，高速液体アフィニティークロマ トグラフィーが発達し, 短時間で精製が可能となってき たが，大量処理には適していない。

我々は酵素などタンパク質の固定化担体としてマグネ タイト微粒子を利用することについて報告した6)。微粒 子状担体は特に $1 \mu \mathrm{m}$ 以下のものになると固定化表面樍 の増大により吸着量が増大し, 反応液中への分散が良く なり迅速な吸着操作が可能となるが, 逆に回収が困難と なる．その解決法として吸着担体を磁性酸化鉄とすれば, 磁場により容易に回収することができる. Lilly らは磁 性酸化鉄粉を含んだポリアクリルアミドゲルビーズに酵 
素基質を固定化し，酵素のアフィニティ一精製を試みて いる゙”。しかし，乙の方法では微粒子状にすることは困 難である.そこで我々は IgGタイプの抗体に特異的に吸 着するプロテイン A 磁性酸化鉄であるマグネタイト微 粒子に固定化し，モノクローナル抗体の迅速かつ簡便な 精製法について検討した.

\section{1. 実 験 方 法}

担体のマグネタイト微粒子は, 我々が開発した方法に したがって磁性流体より調製した ${ }^{6 !}$. マグネタイト微粒 子をトルエン中で $60^{\circ} \mathrm{C}, 1$ 時間, 3 -アミノプロピルトリ エトキシシラン (東京化成) と反応させてアミノ基を導 入し, 次に $10 \%$ グルタルアルデヒド溶液（東京化成） $\left(0.1 \mathrm{~mol} / l\right.$ リン酸緩衝液, $\mathrm{pH} 7.0,0^{\circ} \mathrm{C}, 1$ 時間) により 活性化した。水で洗浄後, 活性化マグネタイトをプロテ インA (Genzyme Corporation, Boston, USA) 溶液(0.1 $\mathrm{mol} / l$ リン酸緩衝液, $\mathrm{pH} 7.0)$ に再懸濁した $\left(4^{\circ} \mathrm{C}, 12\right.$ 時 間).乙の微粒子を $1 \mathrm{~mol} / l \mathrm{NaCl}$ 溶液, リン酸緩衝液で 洗浄した後, リン酸緩衝生理的食垍水 (以下PBS) $(\mathrm{pH}$ $7.3)$ に懸濁し， $4^{\circ} \mathrm{C}$ で保存した。 タンパク質の定量は Lowry らの方法 ${ }^{5)}$ により行った. また, マグネタイトの 定量は塩酸で溶解後, 原子炎光分析により行った。

固定化されたプロティンAの吸着定数を決定するため, プロテイン $\mathrm{A}$ 固定化マグネタイトに任意の濃度 $\left[E_{0}\right]$ のマ ウス IgG溶液を加え, 吸着反応を行い, マグネタイトを 磁石で回収し，上清液を分取した。上清液中のマウス $\operatorname{IgG}$ 濃度を遊離の抗体濃度 $[E]$ とし， $\left[E_{0}\right]$ から $[E]$ を差 し引いた值をマウス IgGとプロティンA固定化マグネタ イトとの複合体濃度 $[E L]$ とした．また，マウス $\operatorname{IgG}$ 濃 度は酵素免疫定量法 ${ }^{3)}$ (ELISA 法)によって测定した。

プロティン $\mathrm{A}$ 固定化マグネタイトに吸着したマウス IgG を溶離するための溶出剂の検討は次のように行った. まず, プロテイン A 固定化マグネタイトをマウス IgG溶 液に加え，吸着反応を行い，磁石でマグネタイトを回収 し上清液を分取した。 上清液中のマウス $\operatorname{IgG}$ 量を最初に 加えた量から差し引き, 吸着量とした。マウス IgGの吸 着したマグネタイトをPBSで洗浄し，溶出剂により溶 出し, この溶出液中のマウス IgG 量を溶出量とした。溶 出剂としては: グリシンー塩酸緩衝液 $(0.1 \mathrm{~mol} / l)$, チオ シアン酸カリウム $(0.1 \mathrm{~mol} / l$ リン酸緩衝溶液 $\mathrm{pH} 7.0)$, 尿素 (PBS 溶液) および，グアニジン塩酸を用い検討を行 った。また，グリシンー塩酸緩衝液で溶出したものにつ いては, 溶出後直ちに $2.5 \mathrm{~mol} / l$ リン酸緩衝液 $(\mathrm{pH} 8.0)$ により中和した。溶出後, 回収したプロティンA 固定化 マグネタイトはPBSで洗浄し，再吸着反応を行い，再吸 着量を求めた。乙れら溶出量と再吸着量が良好な溶出剤 を最適な溶出剤とした。また，プロテイン A 固定化マグ
Table 1 Elution of mouse IgG adsorbed on protein A - magnetite

\begin{tabular}{|c|c|c|c|}
\hline \multicolumn{2}{|c|}{ Eluent } & $\begin{array}{c}\text { Recovery of } \\
\operatorname{IgG}^{11}\end{array}$ & $\begin{array}{l}\text { Regeneration } \\
\text { of Rrotein A - } \\
\text { Magnetite }\end{array}$ \\
\hline \multirow{4}{*}{$\begin{array}{l}\text { glycine- } \\
\mathrm{HCl} \text { buffer }\end{array}$} & $\mathrm{pH} 2.0$ & 76 & 104 \\
\hline & $\mathrm{pH} 2.2$ & 67 & 101 \\
\hline & $\mathrm{pH} 2.5$ & 58 & - \\
\hline & $\mathrm{pH} 3.0$ & 1 & - \\
\hline \multirow{2}{*}{$\mathrm{KSCN}$} & $1 \mathrm{M}$ & 14 & 37 \\
\hline & $2 \mathrm{M}$ & 13 & 43 \\
\hline urea & $2 \mathrm{M}$ & 6.5 & 0 \\
\hline \multirow{3}{*}{$\begin{array}{l}\text { guanidine- } \\
\mathrm{HCl}\end{array}$} & $1 \quad M$ & $<3$ & - \\
\hline & $2 \mathrm{M}$ & 71 & 83 \\
\hline & $4 \mathrm{M}$ & - & 67 \\
\hline
\end{tabular}

1) Recovery of $\operatorname{IgG}=\frac{(\text { eluted } \operatorname{IgG})}{(\text { adsorbed IgG) }} \times 100$

2) $\begin{aligned} & \text { Regeneration of } \\ & \text { Protein A-Magnatite }\end{aligned}=\frac{\left(\begin{array}{l}\text { adsorbed } \mathrm{IgG} \\ \text { at second use }\end{array}\right)}{\left(\begin{array}{l}\text { adsorbed IgG } \\ \text { at first use }\end{array}\right)} \times 100$

ネタイトの繰り返し使用は, 溶出剂としてグリシンー塩 酸緩衝液 $(\mathrm{pH} 2.0)$ を用いて行った.

ハイブリドーマ培養液からのモノクローナル莯体の精 製方法は次のようである. マウスハイブリドーマ $16-3 \mathrm{~F}$ 株 ${ }^{4)}$ 培養上清液 (DF 培地 $+10 \%$ 牛胎児血清) の $50 \%$ 飽和 硫安分画をマウス $\mathrm{IgG}$ 粗抗体液とした. $10 \mathrm{mg}$ のプロテ イン A 固定化マグネタイトを粗抗体液 $6.0 \mathrm{ml}$ に加え, 抗 体を吸着させ, PBSで洗浄後, $0.1 \mathrm{~mol} / l$ グリシン一塩酸 緩衝液 (pH 2.0) $6.0 \mathrm{ml}$ を加えて吸着した抗体を溶出し た. プロテイン A 固定化マグネタイトを磁気分離した後, 上清液を分別して $2.5 \mathrm{~mol} / l$ リン酸緩衝液 $(\mathrm{pH} 8.0) 1.2 \mathrm{~m} l$ により中和した. 全タンパク質量, 抗体量はLowryらの 方法 ${ }^{5)}$ およびELISA 法 $^{3)}$ により行った.

\section{2. 実験結果および考察}

本研究で使用したプロテイン Aがほぼ純粋であること をポリアクリルアミド電気泳動法で確認した後, プロテ イン $\mathrm{A}$ 固定化マグネタイトのタンパク質量と鉄の定量值 からプロテインAの固定化量を算出した．本実験で得ら れたプロテイン $\mathrm{A}$ 固定化量はマグネタイト $1 \mathrm{~g}$ 当たり約 $80 \mathrm{mg}$ であった。 この值は先に報告した ${ }^{6)}$ 各種酵素の固 定化量と比較して妥当な値である.

次にプロテインA固定化マグネタイトの吸着定数を決 定した。.Fig. 1 に示すように, 液中の抗体濃度が $4 \times 10^{-7}$ $\mathrm{mol} / l(27 \mathrm{mg} / l)$ 以上で吸着量はほぼ一定となった。 Fig. 1 中に示した Scatchard plotの傾きより吸着定数 $K_{a}$ は $9 \times 10^{6} l / \mathrm{mol}$ であった. 本実験で用いたマウス IgG に対する遊離のプロティンA の吸着定数をELISA方法 ${ }^{3)}$ で求めたところ $4.7 \times 10^{7} \mathrm{l} / \mathrm{mol}$ であった. この值に対し, 
Table 2 Purification of mouse IgG antibody with protein A - magnetite

\begin{tabular}{|c|c|c|c|c|c|}
\hline & $\begin{array}{l}\text { Total } \\
\text { protein } \\
\text { (mg) }\end{array}$ & $\begin{array}{l}\text { Mouse } \\
\text { IgG } \\
(\mathrm{mg})\end{array}$ & $\begin{array}{l}\text { Purification } \\
\qquad(-)\end{array}$ & $\begin{array}{l}\text { Purity } \\
(\%)\end{array}$ & $\begin{array}{c}\text { Recovery } \\
(\%)\end{array}$ \\
\hline Crude & 5.30 & 0.18 & 1 & 3.4 & \\
\hline $\begin{array}{l}\text { Protein A-magnetite } \\
\text { adsorbed } \\
\text { washed }\end{array}$ & & $\begin{array}{l}0.16 \\
0.02\end{array}$ & & & 100 \\
\hline Eluate & 0.15 & 0.11 & 21 & 73 & 69 \\
\hline
\end{tabular}

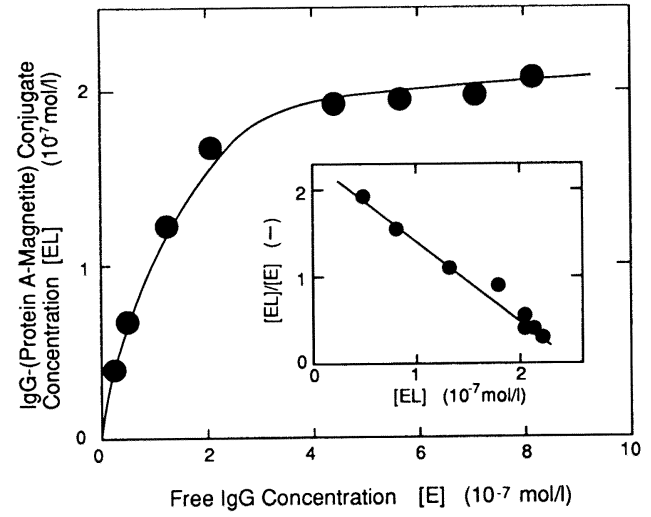

Fig. 1 Adsorption equilibrium curve and scatchard plot (inner graph) of protein A-magnetite

本実験で得られたプロテイン $\mathrm{A}$ 固定化マグネタイトの値 が低い理由として，固定化による立体障害などの影響が 考えられうる。

プロテインA 固定化マグネタイトに吸着したマウス $\operatorname{IgG}$ を溶離するためつ溶出剤の検討を行った．Table 1 に示 すように回収率, 再生率ともに高いのは $\mathrm{pH} 2.0$ のグリシ ンー塩酸緩衝液と $2 \mathrm{~mol} / \mathrm{l}$ グアニジン塩酸であったが, その後の繰り返し使用では $2 \mathrm{~mol} / l$ グアニジン湓酸で溶 出した場合, 4 回目以降の再生率が低下 $(35 \%$ 以下, デー タ示さず) したため, 溶出液として $\mathrm{pH} 2.0$ のグリシンー 塩酸緩衝液を用いることとした。プロテイン $\mathrm{A}$ のマウス $\mathrm{IgG}$ 溶出は通常 $\mathrm{pH} 3$ 程度で行われ，抗体活性の回収の ためには $\mathrm{pH}$ は高いほうが良い。しかし本実験では $\mathrm{pH}$ 3.0 ではほとんど溶出されず， $\mathrm{pH} 2.5$ で回収率は $58 \%$ ，ま た $\mathrm{pH} 2.0$ のときでも約 $76 \%$ とH を下げなければ溶出で きなかった。また，プロテイン $\mathrm{A}$ 固定化マグネタイトを 7 回繰り返し使用したところ吸着量抢よび溶出量ともに ほぼ一定で，回収率（溶出量の吸着量に対する割合）は 約 60\%であった。

Table 2 にプロテインA 固定化マグネタイトによるマ ウス $\operatorname{lgG}$ 精製の結果を示す．プロテイン A 固定化マグネ タイトによる精製により純度 $73 \%$ の抗体が得られた。ま

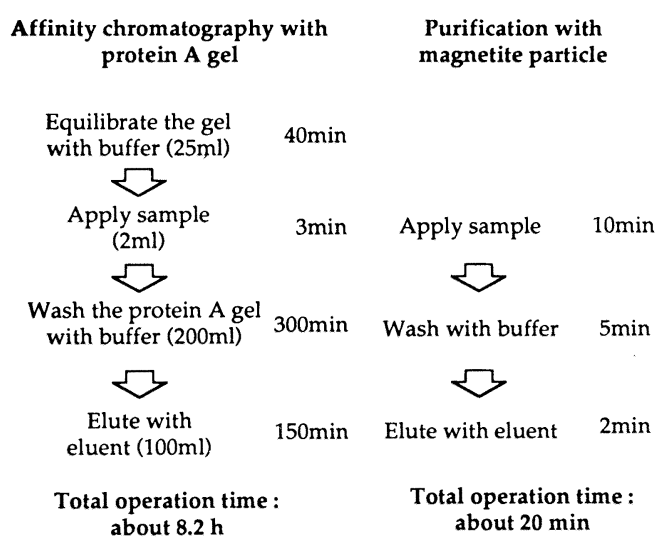

Fig. 2 Comparison of purification operations

た，精製度は 21 倍，回収率は $69 \%$ であった。溶出液の SDS - ポリアクリルアミド電気泳動を行ったところ，ほ とんど夾雑タンパク質のバンドは見られなかった。

Fig. 2 亿本研究によ.るモノクローナル抗体の精製法と 従来のカラムクロマトグラフィーによる方法との比較を 行った。従来法の例としてはプロテインAをセファロー ス CL -4B ゲル (ファルマシア) に固定化し，てれをべッ ド体積 $5 \mathrm{~m} l$ のカラムに充填した場合を考え，マウス腹水 の $50 \%$ 飽和硫安分画からのモノクローナル抗体の精製に ついて検討した。また，本研究による方法は粗抗体液か らの精製法である，従来法が力ラムの平衡化を含めて約 8 時間であるのに対し，本実験方法では 20 分と短時間で 操作は完了する。 また従来法ではスケールアップした際, カラム操作が主であるので操作時間が処理量に比して增 すのに対し，本実験方法では基本的に操作時間に変化は ないと考えられる。このようにマグネタイト微粒子をア フィニティー精製用担体として用いたため, 迅速かつ簡 便にモノクローナル抗体を精製することが可能となった。 な押，本研究では一例としてプロテインAをマグネタ イトに固定化してモノクローナル抗体の精製に応用した が，アフィニティークロマトグラフィーが適用されるシ ステムがあれば基本的には本法の応用が可能である。 


\section{Literature cited}

1) Dunnill, P. and M.D. Lilly: Biotechnol. Bioeng., 16, 987 (1974)

2) Engvall, E. and P. Pearlmann: Immunochemistry, 8, 871 (1971)

3) Friguet, B., A.F. Chaffotte, L. Djavadi-Ohaniance and M.E. Goldberg: J. Immuno Method, 77, 305
(1985)

4) Kamihira, M., I. Kawakubo, M. Taniguchi, S. Iijima and T. Kobayashi: J. Chem. Eng. Japan, 21, 357 (1988)

$5)$ Lowry, O.H., N.J. Resebrough, A.L. Farr and R.J. Randall : J. Biol. Chem., 193, 295 (1951)

6) Shinkai, M., H. Honda and T. Kobayashi: Biocatalysis, 5, 61 (1991)

\title{
Rapid Purification of Monoclonal Antibody with Functional Magnetite Particles
}

\author{
Masashige Shinkai, Masamichi Kamihira, Hiroyuki Honda \\ and Takeshi Kobayashi
}

Dept. of Biotechnology, Faculty of Engineering, Nagoya Univ., Nagoya 464-01

\begin{abstract}
Key Words : Biochemical Engineering, Purification Technique, Affinity Separation, Magnetite Particles, Monoclonal Antibody, Protein A

We have developed a rapid method of purifying monoclonal antibody with functional magnetite particles. Protein $\mathrm{A}$, which has an affinity to IgG-type antibody, was immobilized on magnetite particles. The affinity constant of protein A-magnetite to mouse IgG was $9 \times 10^{6} \mathrm{l} / \mathrm{mol}$. Using such particles, purified antibody of $73 \%$ purity was obtained with $60 \%$ recovery from mouse hybridoma culture broth. These affinity particles could be regenerated and reused. Using magnetite particles for affinity purification, total operation time was shortened to about $20 \mathrm{~min}$.
\end{abstract}

\section{シリコーンゴム中空糸膜による窒素中の有機溶剤蒸気 濃縮操作の温度依存性 ${ }^{\dagger}$}

\author{
伊東 章・田崎慶蔵 ${ }^{*}$. 藤井盈宏 \\ 新潟大学工学部 化学システム工学科 $^{\dagger \dagger}$
}

排気中に含末れるフロンガス等の有機溶剤蒸気の回収 方法之して膜分離㙅作が検討されている. しかし, 操作 条件として温度の影響を指摘したもの ${ }^{11}$ はあるが, 実験 的に検討したものは無い.

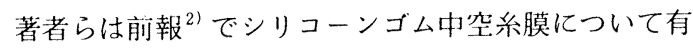

† 1991年 9 月 7 日受理；化学工学会第56年会 (東京, 1991年 3 月）にて発表

†† 950-21 新潟市五十嵐 2 の町 8050

* 新潟システムエンジニアリング (侏)
機蒸気の透過係数を測定し, 窒素との混合気体透過実験 と比較した。本研究ではこれに続いて，低温下で有機蒸 気の透過係数が増加して窒素に対する理想分離係数が増 加する点に着目して, 有機蒸気透過係数の温度依存性を 調べ, 窒素との混合気体の透過分離実験を行った。

シリコーンゴム膜の有機蒸気透過係数温度・分圧依存 性

本研究で使用した膜は永柳工業㑣製の外径 $320 \mu \mathrm{m}$, 内 径 $200 \mu \mathrm{m}$ のシリコーンゴム製均質中空糸膜である ${ }^{2)}$. 有 